The University of San Francisco

USF Scholarship: a digital repository@ Gleeson Library | Geschke Center

2000

\title{
Thermodynamic Stability of Sn4, Sn5, Sn6, and Sn7 Clusters by Knudsen Cell Mass Spectrometry
}

Giovanni Meloni

University of San Francisco, gmeloni@usfca.edu

RW. Schmude

J E. Kingcade

Karl A. Gingerich

Follow this and additional works at: http://repository.usfca.edu/chem_fac

Part of the Chemistry Commons

\section{Recommended Citation}

Meloni, G., Schmude, R. W., Kingcade, J. E., \& Gingerich, K. A. (2000). Thermodynamic stability of Sn[sub 4], Sn[sub 5], Sn[sub 6], and $S n$ [sub 7] clusters by Knudsen cell mass spectrometry. Journal Of Chemical Physics, 113(5)

This Article is brought to you for free and open access by the Chemistry at USF Scholarship: a digital repository @ Gleeson Library|Geschke Center. It has been accepted for inclusion in Chemistry Faculty Publications by an authorized administrator of USF Scholarship: a digital repository @ Gleeson Library | Geschke Center. For more information, please contact repository@usfca.edu. 


\title{
Thermodynamic stability of $\mathrm{Sn}_{4}, \mathrm{Sn}_{5}, \mathrm{Sn}_{6}$, and $\mathrm{Sn}_{7}$ clusters by Knudsen cell mass spectrometry
}

\author{
G. Meloni, R. W. Schmude, Jr., ${ }^{\text {a) }}$ J. E. Kingcade, Jr., ${ }^{\text {b) }}$ and K. A. Gingerich ${ }^{\text {c) }}$ \\ Department of Chemistry, Texas A\&M University, P.O. Box 30012, College Station, Texas 77842-3012
}

(Received 3 April 2000; accepted 5 May 2000)

\begin{abstract}
The Knudsen cell mass spectrometric method has been employed to measure the partial pressures of $\mathrm{Sn}_{n}(n=1-7)$ under equilibrium conditions above liquid tin or a tin-gold alloy, contained in a graphite Knudsen cell. From the all-gas analyzed equilibria the following atomization enthalpies $\Delta_{a} H_{0}^{\circ}\left(\mathrm{Sn}_{n}\right)$, and enthalpies of formation, $\Delta_{f} H_{298.15}^{\circ}\left(\mathrm{Sn}_{n}\right)$, in $\mathrm{kJ} \mathrm{mol}{ }^{-1}$, have been obtained: $\mathrm{Sn}_{4}$,

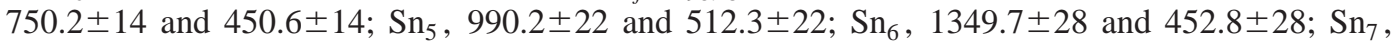
$1644.2 \pm 37$ and $460.0 \pm 37$. The atomization energies are compared with available theoretical values. (C) 2000 American Institute of Physics. [S0021-9606(00)02029-8]
\end{abstract}

\section{INTRODUCTION}

In recent years, there has been a large amount of research focused on the thermodynamic, electronic, and physical properties, and on the structure and reactivity of small inorganic clusters. The recent development of laser vaporization coupled with molecular beam technology has resulted in numerous studies of gas phase metal and semiconductor clusters. ${ }^{1}$ This interest arises from their unique physical properties, ${ }^{2}$ from the vital role that they play in the nucleation processes, ${ }^{3,4}$ from their potential use as functional units in quantum computers, ${ }^{5}$ and from their potential use as catalysts. ${ }^{6,7}$

The present investigation of the tin clusters $\mathrm{Sn}_{4}-\mathrm{Sn}_{7}$ has been part of our systematic investigation of thermodynamic properties of small group 14 clusters from Knudsen effusion measurements with a mass spectrometer. ${ }^{8-12}$ These investigations contribute to the knowledge of their thermodynamic properties and, together with the relevant spectroscopic and theoretical studies, to the knowledge of the bonding in such clusters.

The first mass spectrometric observation of tin clusters, $\mathrm{Sn}_{2}^{+}-\mathrm{Sn}_{5}^{+}$, has been reported by Honig, who evaporated tin from an open fused silica crucible. ${ }^{13}$ Drowart and Goldfinger ${ }^{14}$ have estimated the atomization energies of $\mathrm{Sn}_{3}$ and $\mathrm{Sn}_{4}$ from Honig's data. Gingerich et al. ${ }^{11}$ evaporated tin from a graphite Knudsen cell and derived the third-law atomization energies of $\mathrm{Sn}_{2}-\mathrm{Sn}_{7}$, assuming linear geometries for the tin clusters.

The first theoretical study of $\mathrm{Sn}_{2}-\mathrm{Sn}_{7}$, using a molecular orbital method, was reported by Anderson. ${ }^{15}$ His calculations predicted linear, diamond, trigonal pyramid, hexagonal, and double capped pentagon geometries as the most stable structures for $\mathrm{Sn}_{3}, \mathrm{Sn}_{4}, \mathrm{Sn}_{5}, \mathrm{Sn}_{6}$, and $\mathrm{Sn}_{7}$, respectively. The

\footnotetext{
${ }^{a}$ Present address: Division of Natural Science and Nursing, Gordon College, 419 College Dr., Barnesville, Georgia 30204.

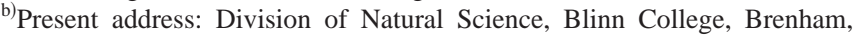
Texas 77833 .

${ }^{c)}$ Electronic mail: gingeric@mail.chem.tamu.edu
}

computed bond energies were smaller than the corresponding experimental values. ${ }^{11}$

In recent years there has been an increasing number of experimental $^{16-32}$ and theoretical ${ }^{26,33-36}$ investigations of small tin clusters.

In several mass spectrometric investigations of nonequilibrium vapor information on the relative stabilities of small tin clusters under various conditions of clusters formation was obtained. Vaporization by resistance heating ${ }^{16}$ or laser vaporization $^{19}$ and subsequent cluster formation by cooling with He gas and ionization of the neutral clusters by $70 \mathrm{~V}$ electrons ${ }^{16}$ or photoionization ${ }^{19}$ were used in one set of investigations. Noda and co-workers ${ }^{20,21}$ analyzed the tin cluster ions from a liquid metal ion source. With this method clusters containing up to seven atoms were observed and enhanced stability was indicated for $\mathrm{Sn}_{4}^{+}$and $\mathrm{Sn}_{6}^{+},{ }^{20}$ whereas the gas evaporation methods also produced intermediate size clusters with more than ten atoms and indicated preferred stability for $n=4,6$, and 10 . All investigators found that the Sn clusters behave similarly to those of silicon and germanium, having semiconductorlike covalent bonding. In comparing tin and lead clusters LaiHing et al. ${ }^{19}$ found a similar behavior, especially local maxima for $n=10$ for Si through $\mathrm{Pb}$, whereas Saito and $\mathrm{Noda}^{21}$ found the mass spectra for $\mathrm{Pb}$ clusters to be different, reflecting metallic bonding. Ren and Ervin $^{25}$ studied the chemical reactivity of tin and lead cluster anions with oxygen by using a flow-tube reactor; they found there was a large variation in reactivity depending on cluster sizes. Ganteför et al. ${ }^{22,23}$ and Moravec et $a l^{27}$ observed the anion photoelectron spectra of tin clusters gaining important informations about the ground and low-lying electronic states of the neutral species, and measured their electron affinities (EA). Shvartsburg and Jarrold ${ }^{28}$ characterized the structures of tin clusters cations using a tandem quadrupole drift tube apparatus to measure the relative ion mobilities. Bachels et al. ${ }^{30,31}$ used a micromechanical calorimeter in combination with a high-vacuum molecular beam apparatus to investigate thermal properties of isolated tin clusters, such as the formation enthalpy per atom. Yoshida and Fuke ${ }^{29}$ examined the photoionization threshold of tin clusters with up 
to 41 atoms by laser photoionization with mass spectrometric detection and measured their ionization potentials. Negishi et al. $^{32}$ studied the electronic properties of tin cluster anions and chlorine doped tin cluster anions and measured the threshold energies and the HOMO-LUMO gaps and electron affinities of $\operatorname{Sn}_{n}(n=4-41)$. They found that the $\mathrm{Sn}_{n}$ clusters with less than 30 atoms are semiconductor clusters, similar to the $\mathrm{Si}_{n}$ and $\mathrm{Ge}_{n}$ clusters.

In continuation of our studies of the thermodynamic stabilities of small tin clusters, ${ }^{11,17}$ we report here our results for the atomization energies and enthalpies of the formation of $\mathrm{Sn}_{4}-\mathrm{Sn}_{7}$. Our experimental values for the atomization energies are also compared with recent theoretical results from the literature. They have also been used, together with the experimental values for the electron affinities by Moravec et al. ${ }^{27}$ to derive the atomization energies of the corresponding cluster anions.

\section{EXPERIMENT}

The Knudsen effusion mass spectrometric method was employed to measure the partial pressures of $\mathrm{Sn}_{4}, \mathrm{Sn}_{5}, \mathrm{Sn}_{6}$, and $\mathrm{Sn}_{7}$ clusters under equilibrium conditions. The experiments were performed with a Nuclide Corporation 12-90 HT single focusing magnetic deflection-type mass spectrometer. Details of the instrument and experimental procedure have been described elsewhere. ${ }^{37}$

The tin molecules, $\mathrm{Sn}_{4}-\mathrm{Sn}_{7}$, were observed and measured in three different investigations. In series 1, a binary $\mathrm{Sn}-\mathrm{Au}$ alloy in the molar ratio of 4.2:1.0 was contained within a graphite Knudsen cell. A graphite lined tantalum cell containing a 0.99 mole fraction of tin with minor traces of $\mathrm{Cu}, \mathrm{Ag}$, and $\mathrm{Au}$ was employed in series 2. The sample used in series 3 was tin inside a graphite cell. The electron energy used in each of the three series was 17,18 , and $20 \mathrm{~V}$, respectively. More details about the experimental parameters used in these investigations can be found in Ref. 17. All gaseous species were identified from their mass-to-charge ratio, isotopic abundance, and ionization efficiency. At each measurement a movable slit was interposed into the molecular beam to distinguish between ions produced from species in the beam and from residual gases with the same mass-tocharge ratio in the ionization region of the mass spectrometer. The ionization energy of $\mathrm{Sn}_{4}$ was measured as $8.7 \pm 1.0$ $\mathrm{eV}$, using the literature ionization energies of $\mathrm{Sn}, 7.34 \mathrm{eV}{ }^{38}$ and of $\mathrm{Au}, 9.22 \mathrm{eV},{ }^{38}$ to calibrate the electron energy scale. The ion currents of $\mathrm{Sn}_{5}^{+}, \mathrm{Sn}_{6}^{+}$, and $\mathrm{Sn}_{7}^{+}$were too small for obtaining the respective ionization energies. The measured ion intensities of $\mathrm{Sn}^{+}, \mathrm{Sn}_{4}^{+}, \mathrm{Sn}_{5}^{+}, \mathrm{Sn}_{6}^{+}$, and $\mathrm{Sn}_{7}^{+}$, pertinent to the present investigation are listed in Table I.

The reference pressure calibration constant for atomic tin, $k_{\mathrm{Sn}}$, was determined from the known $\operatorname{Sn}_{2}(g)=2 \operatorname{Sn}(g)$ dissociation reaction, by combining the ion intensities of $\mathrm{Sn}^{+}$and $\mathrm{Sn}_{2}^{+}$, and the literature values of the dissociation enthalpy of $\operatorname{Sn}_{2}(g)\left(D_{0}^{\circ}=183.4 \mathrm{~kJ} \mathrm{~mol}^{-1}\right){ }^{39}$ The necessary Gibbs energy functions of $\operatorname{Sn}(g)$ were taken from Gurvich et $a l .{ }^{40}$ and those for $\mathrm{Sn}_{2}(g)$ were calculated using the molecular parameter determined by Pak et al. ${ }^{39}$ and the electronic excited states measured by Ho et al. ${ }^{41}$ In these calcu- lations, the ionization cross section $\sigma$ for $\mathrm{Sn}_{2}$ was assumed to be 1.5 times that of $\operatorname{Sn}(g) ;{ }^{14}$ the multiplier gains were measured several times in series 1 , resulting in $\gamma_{\mathrm{Sn}_{2}} / \gamma_{\mathrm{Sn}}=0.88$. The pressure constants $k_{i}$ for the clusters were then calculated from $k_{i}=k_{\mathrm{Sn}}\left(\sigma_{\mathrm{Sn}} \gamma_{\mathrm{Sn}} n_{\mathrm{Sn}}\right) /\left(\sigma_{i} \gamma_{i} n_{i}\right)$, where $\sigma, \gamma$, and $n$ are the cross section, multiplier gain, and isotopic abundance, respectively. The cross section for Sn was taken from Freund et $a ._{.}{ }^{42}$ and the molecular cross sections were assumed as 0.75 times the sum of the atomic value. The $\gamma_{i} / \gamma_{\mathrm{Sn}}$ ratio used was equal to that measured for $\mathrm{Sn}_{2}$ and $\mathrm{Sn}$, implying cancellation of the mass and molecular effect. ${ }^{43}$ The resulting values of $k_{i}$, in $\operatorname{bar}^{-1} \mathrm{~K}^{-1}$, are the following for series 1, 2, and 3: Sn, 0.074, 0.605, and 0.064; $\mathrm{Sn}_{4}, 0.084$, 0.687, and 0.072; $\mathrm{Sn}_{5}, 0.078,0.640$, and $0.068 ; \mathrm{Sn}_{6}, 0.075$, 0.614 , and $0.065 ; \mathrm{Sn}_{7}, 0.577$ and 0.061 , for series 2 and 3, respectively.

\section{RESULTS AND DISCUSSION}

\section{A. Thermal functions}

The Gibbs energy functions, $\left(G_{T}^{\circ}-H_{0}^{\circ}\right) / T\left(\mathrm{GEF}_{0}\right)$, and the heat content functions, $\left(H_{T}^{\circ}-H_{0}^{\circ}\right)\left(\mathrm{HCF}_{0}\right)$, needed in the evaluation of the reaction enthalpies were taken from the literature for $\mathrm{Sn}^{40}$ Those for $\mathrm{Sn}_{4}, \mathrm{Sn}_{5}, \mathrm{Sn}_{6}$, and $\mathrm{Sn}_{7}$ were calculated according to the statistical thermodynamic procedures, using the harmonic oscillator-rigid rotator approximation. ${ }^{44}$ The geometries and bond lengths are shown in Fig. 1. The structures of $\mathrm{Sn}_{4}, \mathrm{Sn}_{5}, \mathrm{Sn}_{6}$, and $\mathrm{Sn}_{7}$ clusters and the relative molecular parameters were obtained from Jackson, ${ }^{45}$ which are revised values of those in Jackson et al. ${ }^{26}$ The optimized molecular parameters of these molecules were obtained by local spin density calculations (LSD), carried out using the Hedin-Lundqvist (HL) exchange-correlation functional with the von Barth and He$\operatorname{din}(\mathrm{vBH})$ modification.

The $\mathrm{Sn}_{4}$ ground state, ${ }^{1} A_{g}$, has a planar rhombus geometry $\left(D_{2 h}\right)$ with $\mathrm{Sn}-\mathrm{Sn}$ bond distances of $2.860 \AA$, the short diagonal of $3.078 \AA$, and the smaller bond angle equal to $65.1^{\circ}$. The vibrational frequencies, in $\mathrm{cm}^{-1}$, are $66,91,112$, 140,153 , and 170. Since all of the predicted electronic excited states, calculated by Dai and Balasubramanian, ${ }^{33}$ lie more than $1.0 \mathrm{eV}$ above the ground state, their contribution to the thermal functions below $1900 \mathrm{~K}$ is negligible.

The $\mathrm{Sn}_{5}$ ground state, ${ }^{1} A_{1}^{\prime}$, is a distorted trigonal bipyramid with symmetry reduction to $C_{2 v}$. The bond lengths, in $\AA$, are $3.014(\times 4)$ and $3.008(\times 2)$ for the axial-equatorial distances, and 3.380 for the equatorial-equatorial distance with a bond angle of $107.5^{\circ}$. The vibrational frequencies, in $\mathrm{cm}^{-1}$ are $43,51,59,88,97,103,123,139$, and 151. The following 11 electronic excited states and respective energies, in $\mathrm{cm}^{-1}$, based on theoretical work by Dai and Balasubramanian ${ }^{34}$ were taken into account: ${ }^{3} B_{2}$ (3791), ${ }^{3} B_{1}$ (3791), ${ }^{3} A_{2}$ (4678), ${ }^{1} A_{2}$ (5001), ${ }^{3} E^{\prime \prime}$ (5001), ${ }^{1} B_{2}$ (5968), ${ }^{1} B_{1}$ (5968), ${ }^{1} E^{\prime \prime}$ (6049), ${ }^{3} A_{2}^{\prime}$ (6291), ${ }^{1} A_{1}$ (6372), and ${ }^{3} A_{1}$ (7340).

The $\mathrm{Sn}_{6}$ ground state, ${ }^{1} A_{1 g}$, has a distorted octahedral geometry with a symmetry reduction to $D_{4 h}$. The bond lengths, in $\AA$ are $3.033(\times 8)$ for the axial-equatorial distances and $3.481(\times 4)$ for the equatorial-equatorial dis- 
TABLE I. Measured ion currents, in A, and third-law values, in $\mathrm{kJ} \mathrm{mol}{ }^{-1}$, of the atomization enthalpies, $\Delta_{a} H_{0}^{\circ}$, of the $\mathrm{Sn}_{4}, \mathrm{Sn}_{5}, \mathrm{Sn}_{6}$, and $\mathrm{Sn}_{7}$ clusters.

\begin{tabular}{|c|c|c|c|c|c|c|c|c|c|}
\hline \multirow[b]{2}{*}{$T(\mathrm{~K})$} & \multicolumn{5}{|c|}{ Ion intensities } & \multirow{2}{*}{$\begin{array}{c}\Delta_{a} H_{0}^{\circ} \\
\mathrm{Sn}_{4}\end{array}$} & \multirow{2}{*}{$\begin{array}{c}\Delta_{a} H_{0}^{\circ} \\
\mathrm{Sn}_{5}\end{array}$} & \multirow{2}{*}{$\begin{array}{c}\Delta_{a} H_{0}^{\circ} \\
\mathrm{Sn}_{6}\end{array}$} & \multirow{2}{*}{$\begin{array}{c}\Delta_{a} H_{0}^{\circ} \\
\mathrm{Sn}_{7}\end{array}$} \\
\hline & $\mathrm{Sn}^{+}$ & $\mathrm{Sn}_{4}^{+}$ & $\mathrm{Sn}_{5}^{+}$ & $\mathrm{Sn}_{6}^{+}$ & $\mathrm{Sn}_{7}^{+}$ & & & & \\
\hline \multicolumn{10}{|l|}{ Series 1} \\
\hline 1421 & $2.42 \mathrm{E}-8$ & $3.11 \mathrm{E}-13$ & & & & 750.2 & & & \\
\hline 1448 & $4.12 \mathrm{E}-8$ & $5.70 \mathrm{E}-13$ & & & & 746.3 & & & \\
\hline 1484 & $6.93 \mathrm{E}-8$ & $8.79 \mathrm{E}-13$ & & & & 744.9 & & & \\
\hline 1526 & $1.45 \mathrm{E}-7$ & $2.26 \mathrm{E}-12$ & & & & 740.8 & & & \\
\hline 1563 & $2.15 \mathrm{E}-7$ & $3.40 \mathrm{E}-12$ & & & & 743.9 & & & \\
\hline 1579 & $2.53 \mathrm{E}-7$ & $3.98 \mathrm{E}-12$ & & & & 745.2 & & & \\
\hline 1598 & $2.96 \mathrm{E}-7$ & $4.98 \mathrm{E}-12$ & & & & 748.9 & & & \\
\hline 1611 & $3.82 \mathrm{E}-7$ & $7.95 \mathrm{E}-12$ & & & & 747.7 & & & \\
\hline 1630 & $4.72 \mathrm{E}-7$ & $1.06 \mathrm{E}-11$ & $2.09 \mathrm{E}-13$ & $1.43 \mathrm{E}-13$ & & 749.1 & 982.6 & 1340.2 & \\
\hline 1644 & $5.03 \mathrm{E}-7$ & $9.24 \mathrm{E}-12$ & $2.08 \mathrm{E}-13$ & $1.29 \mathrm{E}-13$ & & 750.3 & 986.5 & 1345.0 & \\
\hline 1662 & $6.44 \mathrm{E}-7$ & $1.13 \mathrm{E}-11$ & $3.20 \mathrm{E}-13$ & $1.43 \mathrm{E}-13$ & & 747.8 & 986.1 & 1340.7 & \\
\hline 1709 & $1.10 \mathrm{E}-6$ & $1.52 \mathrm{E}-11$ & $4.52 \mathrm{E}-13$ & $2.15 \mathrm{E}-13$ & & 743.1 & 980.6 & 1338.8 & \\
\hline 1734 & $1.23 \mathrm{E}-6$ & $1.50 \mathrm{E}-11$ & $3.53 \mathrm{E}-13$ & $9.80 \mathrm{E}-14$ & & 747.6 & 983.2 & 1337.4 & \\
\hline \multirow[t]{2}{*}{1769} & $1.42 \mathrm{E}-6$ & $9.45 \mathrm{E}-12$ & $1.27 \mathrm{E}-13$ & & & 747.7 & 977.3 & & \\
\hline & & & & & Average & $746.7 \pm 2.8^{a}$ & $982.7 \pm 3.5$ & $1340.4 \pm 2.9$ & \\
\hline \multicolumn{10}{|l|}{ Series 2} \\
\hline 1471 & $8.25 \mathrm{E}-9$ & $3.81 \mathrm{E}-13$ & & & & 755.0 & & & \\
\hline 1526 & $1.91 \mathrm{E}-8$ & $1.53 \mathrm{E}-12$ & & & & 758.8 & & & \\
\hline 1523 & $1.72 \mathrm{E}-8$ & $7.95 \mathrm{E}-13$ & & & & 754.3 & & & \\
\hline 1604 & $4.86 \mathrm{E}-8$ & $2.35 \mathrm{E}-12$ & $1.20 \mathrm{E}-13$ & & & 754.1 & 999.2 & & \\
\hline 1648 & $9.78 \mathrm{E}-8$ & $5.05 \mathrm{E}-12$ & $2.55 \mathrm{E}-13$ & $1.94 \mathrm{E}-13$ & & 747.3 & 988.7 & 1344.6 & \\
\hline 1715 & $1.78 \mathrm{E}-7$ & $9.78 \mathrm{E}-12$ & $3.75 \mathrm{E}-13$ & $3.84 \mathrm{E}-13$ & & 753.5 & 991.4 & 1357.8 & \\
\hline 1800 & $3.73 \mathrm{E}-7$ & $2.17 \mathrm{E}-11$ & $1.47 \mathrm{E}-12$ & $6.45 \mathrm{E}-13$ & $7.00 \mathrm{E}-14$ & 759.2 & 1005.2 & 1366.5 & 1650.9 \\
\hline 1855 & $7.19 \mathrm{E}-7$ & 4.53E-11 & $2.42 \mathrm{E}-12$ & $1.09 \mathrm{E}-12$ & $1.26 \mathrm{E}-13$ & 753.7 & 992.7 & 1355.6 & 1639.3 \\
\hline \multirow[t]{2}{*}{1597} & $5.17 \mathrm{E}-8$ & $2.10 \mathrm{E}-12$ & $8.50 \mathrm{E}-14$ & & & 746.0 & 986.1 & & \\
\hline & & & & & Average & $753.5 \pm 4.5$ & $993.9 \pm 7.1$ & $1356.1 \pm 9.0$ & $1645.1 \pm 8.2$ \\
\hline \multicolumn{10}{|l|}{ Series 3} \\
\hline 1552 & $1.95 \mathrm{E}-7$ & $5.20 \mathrm{E}-12$ & & & & 754.7 & & & \\
\hline 1621 & $5.13 \mathrm{E}-7$ & $1.88 \mathrm{E}-11$ & $9.27 \mathrm{E}-13$ & $5.22 \mathrm{E}-13$ & $6.00 \mathrm{E}-14$ & 754.0 & 999.5 & 1353.2 & 1640.8 \\
\hline 1651 & $7.18 \mathrm{E}-7$ & $2.85 \mathrm{E}-11$ & 8.91E-13 & $7.15 \mathrm{E}-13$ & $1.00 \mathrm{E}-13$ & 755.5 & 994.2 & 1354.9 & 1641.8 \\
\hline \multirow[t]{2}{*}{1680} & $9.31 \mathrm{E}-7$ & & & & $1.20 \mathrm{E}-13$ & & & & 1647.7 \\
\hline & & & & & Average & $754.7 \pm 0.7$ & $996.9 \pm 3.7$ & $1354.1 \pm 1.2$ & $1643.4 \pm 3.7$ \\
\hline
\end{tabular}

${ }^{\mathrm{a}}$ The error terms are standard deviations.

tances. The vibrational frequencies, in $\mathrm{cm}^{-1}$, are $46(\times 2)$, 54, 70, 89, 121, 128, $136(\times 2), 160(\times 2)$, and 177.

The $\mathrm{Sn}_{7}$ ground state, ${ }^{1} A_{1}^{\prime}$, is a pentagonal bipyramid $\left(D_{5 h}\right)$ with the bond lengths equal to $3.17 \AA(\times 15)$. The vibrational frequencies, in $\mathrm{cm}^{-1}$, are $53,55,63,69,70,82$ (×2), 94, 104, 108, 109, 122, $133(\times 2), 149$.

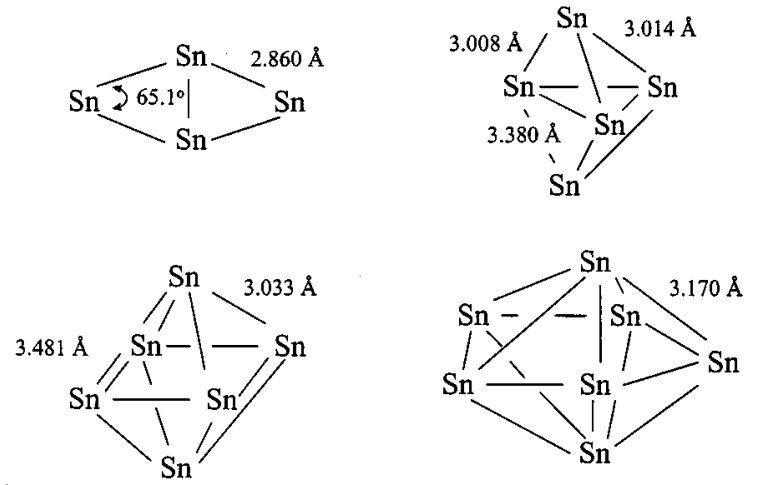

FIG. 1. Structures used in the evaluation of the Gibbs energy functions and the heat content functions listed in Table II.
Table II lists the thermal functions calculated for $\mathrm{Sn}_{4}$, $\mathrm{Sn}_{5}, \mathrm{Sn}_{6}$, and $\mathrm{Sn}_{7}$.

\section{B. Atomization energies and enthalpies of formation}

The enthalpy of the atomization reaction,

$$
\operatorname{Sn}_{n}(g)=n \operatorname{Sn}(g), \quad n=4-7,
$$

TABLE II. The Gibbs energy functions, $\left(G_{T}^{\circ}-H_{0}^{\circ}\right) / T\left(\mathrm{GEF}_{0}\right)$, in $\mathrm{J} \mathrm{K}^{-1} \mathrm{~mol}^{-1}$, and the heat content functions, $H_{T}^{\circ}-H_{0}^{\circ}\left(\mathrm{HCF}_{0}\right)$, in kJ mol${ }^{-1}$, for the $\mathrm{Sn}_{4}, \mathrm{Sn}_{5}, \mathrm{Sn}_{6}$, and $\mathrm{Sn}_{7}$, clusters.

\begin{tabular}{cccccccc}
\hline \hline & \multicolumn{7}{c}{ Temperature (K) } \\
\cline { 2 - 8 } Species & & 298.15 & 1400 & 1600 & 1800 & 2000 & 2200 \\
\hline $\mathrm{Sn}_{4}$ & $-\mathrm{GEF}_{0}$ & 319.9 & 437.7 & 448.4 & 457.9 & 466.4 & 474.1 \\
& $\mathrm{HCF}_{0}$ & 20.87 & 112.1 & 128.7 & 145.4 & 162.0 & 178.6 \\
$\mathrm{Sn}_{5}$ & $-\mathrm{GEF}_{0}$ & 369.9 & 525.9 & 540.8 & 554.3 & 566.6 & 577.9 \\
& $\mathrm{HCF}_{0}$ & 27.56 & 155.0 & 181.6 & 208.3 & 234.7 & 260.6 \\
$\mathrm{Sn}_{6}$ & $-\mathrm{GEF}_{0}$ & 384.2 & 570.4 & 587.4 & 602.6 & 616.1 & 628.5 \\
& $\mathrm{HCF}_{0}$ & 32.56 & 178.5 & 205.1 & 231.7 & 258.3 & 284.9 \\
$\mathrm{Sn}_{7}$ & $-\mathrm{GEF}_{0}$ & 420.4 & 643.3 & 663.7 & 681.7 & 697.9 & 712.6 \\
& $\mathrm{HCF}_{0}$ & 39.28 & 212.8 & 244.4 & 275.9 & 307.5 & 339.1 \\
\hline \hline
\end{tabular}


TABLE III. Thermodynamic properties for the tin clusters $\mathrm{Sn}_{4}-\mathrm{Sn}_{7}$. All values are in $\mathrm{kJ} \mathrm{mol}^{-1}$.

\begin{tabular}{crrcc}
\hline \hline Cluster & \multicolumn{1}{c}{$\Delta_{a} H_{0}^{\circ}$} & $\Delta_{a} H_{298.15}^{\circ}$ & $\Delta_{f} H_{0}^{\circ}$ & $\Delta_{f} H_{298.15}^{\circ}$ \\
\hline $\mathrm{Sn}_{4}$ & $750.2 \pm 14$ & $754 \pm 14$ & $455 \pm 14$ & $451 \pm 14$ \\
$\mathrm{Sn}_{5}$ & $990.2 \pm 22$ & $994 \pm 22$ & $516 \pm 22$ & $512 \pm 22$ \\
$\mathrm{Sn}_{6}$ & $1349.7 \pm 28$ & $1354 \pm 28$ & $458 \pm 28$ & $453 \pm 28$ \\
$\mathrm{Sn}_{7}$ & $1644.2 \pm 37$ & $1648 \pm 37$ & $465 \pm 37$ & $460 \pm 37$ \\
\hline \hline
\end{tabular}

was evaluated according to the second-law method, based on a least-squares analysis of $\ln K_{p}$ vs $1 / T$ plots, and according to the third-law method, using the relation $\Delta_{r} H_{0}^{\circ}$ $=-R T \ln K_{p}-T \Delta\left[\left(G_{T}^{\circ}-H_{0}^{\circ}\right) / T\right]$.

For $\mathrm{Sn}_{4}$ the second-law atomization enthalpy values obtained from the separate analysis of series 1 and series 2 are in good agreement with the third-law values. From series 1 the second and third law $\Delta_{a} H_{0}^{\circ}$, in $\mathrm{kJ} \mathrm{mol}^{-1}$, are 743.0 \pm 11.8 and $746.7 \pm 2.8$, respectively; from series 2 they are 754.9 \pm 20.2 and $753.5 \pm 4.5$, respectively. The atomization en-

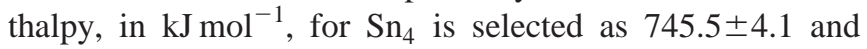
$754.0 \pm 7.1$ for series 1 and series 2 , respectively, giving the third-law value twice the weight of the second-law value. From series 3 only a third-law evaluation is possible, due to few data points and the too small temperature range; the corresponding $\Delta_{a} H_{0}^{\circ}$ value, in $\mathrm{kJ} \mathrm{mol}^{-1}$, is $754.7 \pm 0.7$.

For $\mathrm{Sn}_{5}-\mathrm{Sn}_{7}$ the third-law $\Delta_{a} H_{0}^{\circ}$ values, in $\mathrm{kJ} \mathrm{mol}^{-1}$, of series 1, series 2, and series 3 are $\mathrm{Sn}_{5}, 982.7 \pm 3.5,993.9$ \pm 7.1 , and 996.9 $\pm 3.7 ; \mathrm{Sn}_{6}, 1341.2 \pm 2.7,1356.1 \pm 9.0$, and 1354.1 $\pm 1.2 ; \mathrm{Sn}_{7}, 1645.1 \pm 8.1$ and $1643.4 .0 \pm 3.7$ for series 2 and series 3 , respectively. The atomization enthalpy values of $\mathrm{Sn}_{4}$ and $\mathrm{Sn}_{5}$ clusters are slightly lower than the values reported by Gingerich et al., ${ }^{11}$ whereas the $\Delta_{a} H_{0}^{\circ}$ of $\mathrm{Sn}_{6}$ and $\mathrm{Sn}_{7}$ are higher. This is mainly due to the their different thermal functions used; they were based on an assumed linear structure.

The recommended values for the atomization enthalpies of $\mathrm{Sn}_{4}, \mathrm{Sn}_{5}, \mathrm{Sn}_{6}$, and $\mathrm{Sn}_{7}$ were obtained as the weighted average of the respective selected $\Delta_{a} H_{0}^{\circ}$ value, resulting from each series. The weight for each series was taken as the square root of number of data points. The resulting $\Delta_{a} H_{0}^{\circ}$ values, in $\mathrm{kJ} \mathrm{mol}^{-1}$ or in $\mathrm{eV}$, are $\mathrm{Sn}_{4}, 750.2 \pm 14$ or 7.78 $\pm 0.15 ; \mathrm{Sn}_{5}, 990.2 \pm 22$ or $10.26 \pm 0.23 ; \mathrm{Sn}_{6}, 1349.7 \pm 28$ or $13.99 \pm 0.29 ; \mathrm{Sn}_{7}, 1644.2 \pm 37$ or $17.04 \pm 0.38$. Here the uncertainties are the overall errors obtained as discussed in Schmude et al. ${ }^{46}$ The corresponding values of $\Delta_{a} H_{298.15}^{\circ}$, $\Delta_{f} H_{0}^{\circ}$, and $\Delta_{f} H_{298.15}^{\circ}$ for $\mathrm{Sn}_{4}, \mathrm{Sn}_{5}, \mathrm{Sn}_{6}$, and $\mathrm{Sn}_{7}$ have been derived from the $\Delta_{a} H_{0}^{\circ}$, using $\Delta_{f} H_{0}^{\circ}(\mathrm{Sn}, g)$ $=(301.3 \pm 1.5) \mathrm{kJ} \mathrm{mol}^{-1}, \quad$ and $\quad \Delta_{f} H_{298.15}^{\circ}(\mathrm{Sn}, g)=(301.2$ $\pm 1.5) \mathrm{kJ} \mathrm{mol}^{-1}$, from Gurvich et al. ${ }^{40}$ respectively, and the $H_{298.15}^{\circ}-H_{0}^{\circ}$ values from Table II. The enthalpies of formation were calculated employing the relation $\Delta_{f} H_{T}^{\circ}\left(\operatorname{Sn}_{n}\right)$ $=n \Delta_{f} H_{T}^{\circ}(\mathrm{Sn})-\Delta_{a} H_{T}^{\circ}\left(\operatorname{Sn}_{n}\right)$, where $T$ is 0 or $298.15 \mathrm{~K}$. The thermodynamic properties for $\mathrm{Sn}_{4}-\mathrm{Sn}_{7}$ clusters have been summarized in Table III.

From the $\Delta_{a} H_{0}^{\circ}$ values, the fragmentation energies or incremental dissociation energies, $\Delta_{a} H_{0}^{\circ}\left(\operatorname{Sn}_{n}\right)$ $-\Delta_{a} H_{0}^{\circ}\left(\mathrm{Sn}_{n-1}\right)$, can be derived. They are, in $\mathrm{kJ} \mathrm{mol}^{-1}$ or $\mathrm{eV}, 346$ or $3.59,240$ or $2.49,360$ or 3.73 , and 295 or 3.06 ,
TABLE IV. A comparison of experimental atomization energies, in $\mathrm{eV}$, with recent theoretical values for $\mathrm{Sn}_{4}-\mathrm{Sn}_{7}$.

\begin{tabular}{cccccc}
\hline \hline & \multicolumn{2}{c}{ Experiment } & & \multicolumn{3}{c}{ Theoretical } \\
\cline { 2 - 2 } \cline { 5 - 6 } Cluster & This investigation & & MRSDCI & BLYP $^{\mathrm{a}}$ & CP-MD $^{\mathrm{b}}$ \\
\hline $\mathrm{Sn}_{4}$ & $7.78 \pm 0.15$ & & $7.37^{\mathrm{c}}$ & 8.28 & 10.94 \\
$\mathrm{Sn}_{5}$ & $10.26 \pm 0.23$ & & $9.37^{\mathrm{d}}$ & 10.89 & 14.83 \\
$\mathrm{Sn}_{6}$ & $13.99 \pm 0.29$ & & & 13.92 & 19.00 \\
$\mathrm{Sn}_{7}$ & $17.04 \pm 0.38$ & & & 16.84 & 23.16 \\
\hline \hline
\end{tabular}

${ }^{\mathrm{a}}$ Reference 26.

${ }^{\mathrm{b}}$ Reference 36.

${ }^{\mathrm{c}}$ Reference 33.

${ }^{\mathrm{d}}$ Reference 34 .

for $\mathrm{Sn}_{4}, \mathrm{Sn}_{5}, \mathrm{Sn}_{6}$, and $\mathrm{Sn}_{7}$. Here the $\Delta_{a} H_{0}^{\circ}\left(\mathrm{Sn}_{3}\right)$ of (403.8 $\pm 14.8) \mathrm{kJ} \mathrm{mol}^{-1}$, or $4.19 \mathrm{eV},{ }^{17}$ has been used to obtain the value for $\mathrm{Sn}_{4}$. The values confirm the qualitative conclusions of earlier nonequilibrium mass spectrometric observations of a preferred stability for $\mathrm{Sn}_{4}$ and $\mathrm{Sn}_{6} \cdot{ }^{16,20}$ The stability trend for the tin clusters is similar to that for the corresponding germanium clusters ${ }^{10}$ and silicon clusters. ${ }^{47}$

It is also interesting to calculate the binding energies, or atomization enthalpies, of tin clusters anions for the reaction $\mathrm{Sn}_{n}^{-}(g)=(n-1) \mathrm{Sn}(g)+\mathrm{Sn}^{-}(g)$, using the experimental values of their electron affinities (EA). The results, in $\mathrm{eV}$, are 5.32, 8.71, 11.80, 15.16, and 17.89 for $\mathrm{Sn}_{3}^{-}, \mathrm{Sn}_{4}^{-}, \mathrm{Sn}_{5}^{-}$, $\mathrm{Sn}_{6}^{-}$, and $\mathrm{Sn}_{7}^{-}$, respectively. The relation used is $\Delta_{a} H_{0}^{\circ}\left(\mathrm{Sn}_{n}^{-}\right)=\Delta_{a} H_{0}^{\circ}\left(\mathrm{Sn}_{n}\right)-\mathrm{EA}(\mathrm{Sn})+\mathrm{EA}\left(\mathrm{Sn}_{n}\right)$. The experimental electron affinities were taken from Moravec et al. ${ }^{27}$ for $\mathrm{Sn}_{3}-\mathrm{Sn}_{7}$, and from Thøgersen et al. ${ }^{48}$ for the atomic tin. The corresponding fragmentation enthalpies, $\Delta_{a} H_{0}^{\circ}\left(\mathrm{Sn}_{n}^{-}\right)$ $-\Delta_{a} H_{0}^{\circ}\left(\mathrm{Sn}_{n-1}^{-}\right)$, in $\mathrm{eV}$, are 3.39, 3.09, 3.36, and 2.72 for $\mathrm{Sn}_{4}^{-}, \mathrm{Sn}_{5}^{-}, \mathrm{Sn}_{6}^{-}$, and $\mathrm{Sn}_{7}^{-}$, respectively.

\section{Comparison of experimental and theoretical atomization energies}

In recent years theoretical studies in predicting binding or atomization energies of small group 14 clusters, especially those of carbon and silicon, with chemical accuracy, ${ }^{47}$ using the Gaussian 2 (G2) theory have become possible. The G2 theory has recently ${ }^{49}$ also been applied with similar success to germanium clusters with up to five atoms, ${ }^{10}$ but has not yet been extended to tin clusters.

In Table IV we compare the experimental atomization energies of $\mathrm{Sn}_{4}-\mathrm{Sn}_{7}$ obtained in the present investigation with the corresponding recent theoretical values.

Dai and Balasubramanian performed multireference singles and doubles configuration interaction calculations (MRSDCI) on $\mathrm{Sn}_{4}^{33}$ and $\mathrm{Sn}_{5}^{34}$ giving several electronic excited states with different geometries. The calculated atomization enthalpies are about $5 \%$ for $\mathrm{Sn}_{4}$ and $9 \%$ for $\mathrm{Sn}_{5}$ less than our respective recommended values.

The only theoretical calculations performed so far on $\mathrm{Sn}_{6}$ and $\mathrm{Sn}_{7}$ are those by Jackson et al. ${ }^{26}$ and Wang et al. ${ }^{35}$ Wang et al. performed ab initio total-energy pseudopotential calculations on neutral and negatively charged $\operatorname{Sn}_{n}(n$ $=3-10$ ) clusters, giving the lowest-energy structures without details of the molecular parameters. Jackson et al. ${ }^{26}$ cal- 
culated the energy minimized structures for $\mathrm{Sn}_{2}-\mathrm{Sn}_{7}$ neutral and anionic clusters, also giving the molecular parameters, bond distances, and vibrational frequencies. The atomization enthalpies obtained by single-point calculations using the Becke-Lee-Yang-Parr gradient-corrected correlation functional (BLYP) at the Becke-Janak-Moruzzi-Williams correlation functional (BJMW) optimized geometry with zeropoint corrections, are slightly higher than our values for $\mathrm{Sn}_{4}$ and $\mathrm{Sn}_{5}$, whereas they are in good agreement for $\mathrm{Sn}_{6}$ and $\mathrm{Sn}_{7}$. Lu et al. ${ }^{36}$ carried out the Car-Parrinello ab initio molecular dynamics (CP-MD) simulated annealing of tin clusters up to 13 atoms to gain some insight into the dynamics of clusters formation. They also give values for the cohesive energies of these clusters (see Table IV), which are subject to a constant shift.

\section{ACKNOWLEDGMENTS}

The authors would like to thank the Robert A. Welch Foundation and the National Science Foundation for financial support of this work.

${ }^{1}$ M. D. Morse, Chem. Rev. 86, 1049 (1986).

${ }^{2}$ Y. Oshima and K. Takayanagi, Z. Phys. D: At., Mol. Clusters 27, 287 (1993).

${ }^{3}$ J. Bernholc and J. C. Phillips, Phys. Rev. B 33, 7395 (1986).

${ }^{4}$ Physics and Chemistry of Finite Systems: From Clusters to Crystals, edited by P. Jena, S. N. Khanna, and B. K. Rao (Kluwer Academic, Boston, 1992), Vols. 1 and 2.

${ }^{5}$ N. Hamada, in Microclusters, edited by S. Sugano, Y. Nishina, and S. Ohnishi (Springer-Verlag, Berlin, 1987), p. 180.

${ }^{6}$ D. N. Belton and S. J. Schmieg, Surf. Sci. 202, 238 (1988).

${ }^{7}$ J. Haggin, Chem. Eng. News 65, 9 (1987).

${ }^{8}$ K. A. Gingerich, H. C. Finkbeiner, and R. W. Schmude, Jr., J. Am. Chem. Soc. 116, 3884 (1994).

${ }^{9}$ K. A. Gingerich, Q. Ran, and R. W. Schmude, Jr., Chem. Phys. Lett. 256, 274 (1996).

${ }^{10}$ K. A. Gingerich, R. W. Schmude, Jr., M. Sai Baba, and G. Meloni, J. Chem. Phys. 112, 7443 (2000).

${ }^{11}$ K. A. Gingerich, A. Desideri, and D. L. Cocke, J. Chem. Phys. 62, 731 (1975).

${ }^{12}$ K. A. Gingerich, D. L. Cocke, and F. Miller, J. Chem. Phys. 64, 4027 (1976).

${ }^{13}$ R. E. Honig, J. Chem. Phys. 21, 573 (1953).

${ }^{14}$ J. Drowart and P. Goldfinger, Angew. Chem. Int. Ed. Engl. 6, 581 (1967).

${ }^{15}$ A. B. Anderson, J. Chem. Phys. 63, 4430 (1975).

${ }^{16}$ T. P. Martin and H. Schaber, J. Chem. Phys. 83, 855 (1985)

${ }^{17}$ K. A. Gingerich, E. A. Ramakrishnan, and J. E. Kingcade, Jr., High. Temp. Sci. 21, 1 (1986).

${ }^{18}$ J. C. Phillips, J. Chem. Phys. 87, 1712 (1987).
${ }^{19}$ K. LaiHing, R. G. Wheeler, W. L. Wilson, and M. A. Duncan, J. Chem. Phys. 87, 3401 (1987).

${ }^{20}$ M. Watanabe, Y. Saito, S. Nishigaki, and T. Noda, Jpn. J. Appl. Phys. 27, 344 (1988).

${ }^{21}$ Y. Saito and T. Noda, Z. Phys. D: At., Mol. Clusters 12, 225 (1989).

${ }^{22}$ G. Ganteför, M. Gausa, K. H. Meiwes-Broer, and H. O. Lutz, Faraday Discuss. Chem. Soc. 86, 197 (1988).

${ }^{23}$ G. Ganteför, M. Gausa, K. H. Meiwes-Broer, and H. O. Lutz, Z. Phys. D: At., Mol. Clusters 12, 405 (1989).

${ }^{24}$ D. S. Cornett, M. Peschke, K. LaiHing, P. Y. Cheng, K. F. Willey, and M. A. Duncan, Rev. Sci. Instrum. 63, 2177 (1992).

${ }^{25}$ X. Ren and K. M. Ervin, Chem. Phys. Lett. 198, 229 (1992).

${ }^{26}$ P. Jackson, I. G. Dance, K. J. Fisher, G. D. Willett, and G. E. Gadd, Int. J. Mass Spectrom. Ion Processes 157/158, 329 (1996).

${ }^{27}$ V. D. Moravec, S. A. Klopcic, and C. C. Jarrold, J. Chem. Phys. 110, 5079 (1999).

${ }^{28}$ A. A. Shvartsburg and M. F. Jarrold, Phys. Rev. A 60, 1235 (1999).

${ }^{29}$ S. Yoshida and K. Fuke, J. Chem. Phys. 111, 3880 (1999).

${ }^{30}$ T. Bachels and R. Schäfer, Chem. Phys. Lett. 300, 177 (1999).

${ }^{31}$ T. Bachels, F. Tiefenbacher, and R. Schäfer, J. Chem. Phys. 110, 10008 (1999).

${ }^{32}$ Y. Negishi, K. Kawamata, A. Nakajima, and K. Kaya, J. Electron Spectrosc. Relat. Phenom. 106, 117 (2000).

${ }^{33}$ D. Dai and K. Balasubramanian, J. Chem. Phys. 96, 8345 (1992).

${ }^{34}$ D. Dai and K. Balasubramanian, J. Phys. Chem. 100, 19321 (1996).

${ }^{35}$ B. Wang, L. M. Molina, M. J. López, A. Rubio, J. A. Alonso, and M. J. Stott, Ann. Phys. (Leipzig) 7, 107 (1998).

${ }^{36}$ Z.-Y. Lu, C.-Z. Wang, and K.-M. Ho, Phys. Rev. B 61, 2329 (2000).

${ }^{37}$ K. A. Gingerich, in Current Topics in Material Science, edited by E. Kaldis (North-Holland, Amsterdam, 1980), Vol. 6, p. 345.

${ }^{38}$ C. E. Moore, NRSD-NBS 35, Natl. Bur. Stand. US, 1971.

${ }^{39}$ K. Pak, M. F. Cai, T. P. Dzugan, and V. E. Bondybey, Faraday Discuss. Chem. Soc. 86, 153 (1988).

${ }^{40}$ Thermodynamic Properties of Individual Substances, edited by L. V. Gurvich, I. V. Veyts, and C. B. Alcock (Hemisphere, New York, 1991), Vol. 2.

${ }^{41}$ J. Ho, M. L. Polak, and W. C. Lineberger, J. Chem. Phys. 96, 144 (1992).

${ }^{42}$ R. S. Freund, R. C. Wetzel, R. J. Shul, and T. R. Hayes, Phys. Rev. A 41, 3575 (1990).

${ }^{43}$ M. G. Inghram and R. J. Hayden, Mass Spectrometry (National Academy of Sciences, Washington, DC, 1954).

${ }^{44}$ D. R. Stull and H. Prophet, in Characterization of High Temperature Vapors, edited by J. L. Margrave (Wiley Interscience, New York, 1971), p. 359.

${ }^{45} \mathrm{P}$. Jackson (private communication).

${ }^{46}$ R. W. Schmude, Jr., Q. Ran, and K. A. Gingerich, J. Chem. Phys. 99, 7998 (1993)

${ }^{47}$ K. Raghavachari and L. A. Curtis, in Quantum Mechanical Electronic Structure Calculations with Chemical Accuracy, edited by S. R. Langhoff (Kluwer Academic, The Netherlands, 1995), p. 173.

${ }^{48}$ J. Thøgersen, L. D. Steele, M. Scheer, C. A. Brodie, and H. K. Haugen, J. Phys. B 29, 1323 (1996).

${ }^{49}$ P. W. Deutsch, L. A. Curtiss, and J. B. Blaudeau, Chem. Phys. Lett. 270, 413 (1997). 
Journal of Chemical Physics is copyrighted by AIP Publishing LLC (AIP). Reuse of AIP content is subject to the terms at: http://scitation.aip.org/termsconditions. For more information, see http://publishing.aip.org/authors/rights-and-permissions. 